\title{
Detection of Rhesus Antigens and Rh Phenotype in Donors at National Blood Transfusion Center, Khartoum, Sudan
}

\author{
Mohammed Siddig Younis ${ }^{1 *}$, Hayfa Badawi Saeed Ibrahim² ${ }^{2}$, Albadawi Abdelbagi Talha ${ }^{3}$
}

${ }^{1}$ Department of Medical Laboratory Technology, College of Applied Medica Sciences, Taibah University, Almadina Almonawwarah, Kingdom of Saudi Arabia

${ }^{2}$ Department of Medical Parasitology, Faculty of Medical laboratory science, University of Gezira, Wad Medani, Sudan

${ }^{3}$ Department of Clinical Laboratory Sciences, College of Applied Medical Sciences, Jouf University, Skaka, Kingdom of Saudi Arabia

*Corresponding author: Mohammed Siddig Younis

Abstract

The Rhesus (Rh) blood group system is one of the most polymorphic and immunogenic systems known in humans, because of its immunogenicity along with ABO grouping, This is a cross-sectional study was conducted at national blood transfusion center at Khartoum State to determine the frequency of various Rhesus antigens among Sudanese blood donors in order to minimize Rhesus allo-immunization among Blood recipients. It included 200 donors males from different tribes. The blood were collected from volunteers. ABO grouping was performed by slide method and Rhesus grouping was done by tube method using commercially available standard antisera tested (anti-D, anti-C, antic, anti-E, and anti-e). Among the participants (86\%) of donors are $\mathrm{Rh} \mathrm{D}$ positive and (14\%)Rh $\mathrm{D}$ negative, The percentage of Rh Antigens were e (79.5\%), c (68.5\%), C (27\%), and E (18.5\%) respectively.The study shows that the frequencies of the Rhesus antigens were similar to studies in other countries.

Keywords: ABO blood grouping, Rhesus D, Donors, Rh Antigens.

Copyright @ 2020: This is an open-access article distributed under the terms of the Creative Commons Attribution license which permits unrestricted use, distribution, and reproduction in any medium for non-commercial use (NonCommercial, or CC-BY-NC) provided the original author and source are credited.

\section{INTRODUCTION}

The ABO system antigens and Rhesus (Rh) system antigens are beneficial in genetic studies. Resolving some clinical problems, useful in compatibility testing at blood banking, there are different blood group systems antigens, the ABO blood group antigens are e most clinically important in blood transfusion centers. The information about distribution of $\mathrm{ABO}$ and $\mathrm{Rh}$ blood antigens is very important in management of blood bank transfusion centers and to facilitate the transfusion services [1]. The Rh blood group system includes approximately more than 50 antigens on the red cell surface. The most significant antigen in the Rh system is D antigen, because it is most likely to produce an immune system response [2].

The $\mathrm{Rh}$ blood group is important blood group after $\mathrm{ABO}$ in the blood transfusion services, and the D antigen is important antigen among $\mathrm{Rh}$ antigens in blood banking.[2, 3].The $\mathrm{D}$ antibody is produced in patient after stimulation or transfusion with D-positive red blood cells [4].The ABO blood group and D status of blood donors and recipients are always taken into account when RBCs are transfused [5].
Rhesus ( $\mathrm{Rh}$ ) blood group system is the second most important system in blood transfusion after the ABO system. This system was discovered by Landsteiner and Wiener after experiencing problems in transfusion, as even when the $\mathrm{ABO}$ groups were matching they still had problems, including hemolytic disease of the fetus and newborn [6, 7].The $\mathrm{Rh}$ blood group system, unlike the ABO system, has been shown to have 6 common antigens listed as C, c, D, d, E, and e as originally suggested by Fisher after Landsteiner $[6$, 8].There are racial differences in the distribution of these antigens. Rhesus D negative is more common in Caucasians (15\%), whereas R (DCe) is found in $\sim 48 \%$ Afro-Americans but is uncommon in Caucasians with a prevalence of approximately <2\% [9].

All human populations share the same $\mathrm{ABO}$ and Rhesus blood group systems; although they differ in the frequencies and distributions of specific types in different races, ethnic groups, and socio-economic groups or amongst different populations $[10,11]$. 


\section{METHODS}

This is a cross-sectional study was conducted in national blood transfusion center at Khartoum state between January to December 2015. It Included 200 donors males from different Tribes.

Ethical approval for study was obtained by the Ethics Committee of the Ministry of Health, Sudan. Consent forms were used to inform participants about the purposes and objectives of the study.

The blood was collected from volunteers. ABO grouping was performed by slide method and Rhesus grouping was done by tube method using commercially available standard antisera tested (anti-D, anti-C, anti-c, anti-E, and anti-e) The tubes were labeled according to $\mathrm{Rh}$ antisera type for each donor. One drop of typing sera was added to tube according to Rh sera labeling, one drop of the 5\% donor cells suspension was added to each tube and centrifuged for 15 seconds and agglutination reaction was observed.

The information required was taken from the donors' information sheet inclusion criteria of the study were; all donors were male from 18 to 58years and not donated before sex months, negative to blood transmitted diseases. The data were collected, organized, and analyzed using SPSS (Statistical Packages of Social Sciences) 16.

\section{RESULTS}

A total of 200 donors included in this study all of them were males .Distribution of ABO blood group antigens were O (58.5\%), A (22.5\%), B (15.0\%), and $\mathrm{AB}(4.0 \%)$ table 1 The percentage and $\mathrm{Rh} \mathrm{D}$ antigen are $86 \%$ (172) positive and 14\% (28) were negative as shown table 2 the percentage of the $\mathrm{Rh}$ antigens was D (86\%), e (86.5\%), c (79\%), C (21\%), and $\mathrm{E}(26.5 \%)$ respectively in figure 1.

Table-1: Distribution of abo blood group among study population

\begin{tabular}{|c|c|c|}
\hline & Frequency & Percent \% \\
\hline O & 117 & 58.5 \\
\hline A & 45 & 22.5 \\
\hline B & 30 & 15.0 \\
\hline AB & 8 & 4.0 \\
\hline Total & 200 & 100.0 \\
\hline
\end{tabular}

Table-2: Distribution of RH- $d$ in the study population

\begin{tabular}{|c|c|c|}
\hline & Frequency & Percent \\
\hline Positive & 172 & 86.0 \\
\hline Negative & 28 & 14.0 \\
\hline Total & 200 & 100.0 \\
\hline
\end{tabular}

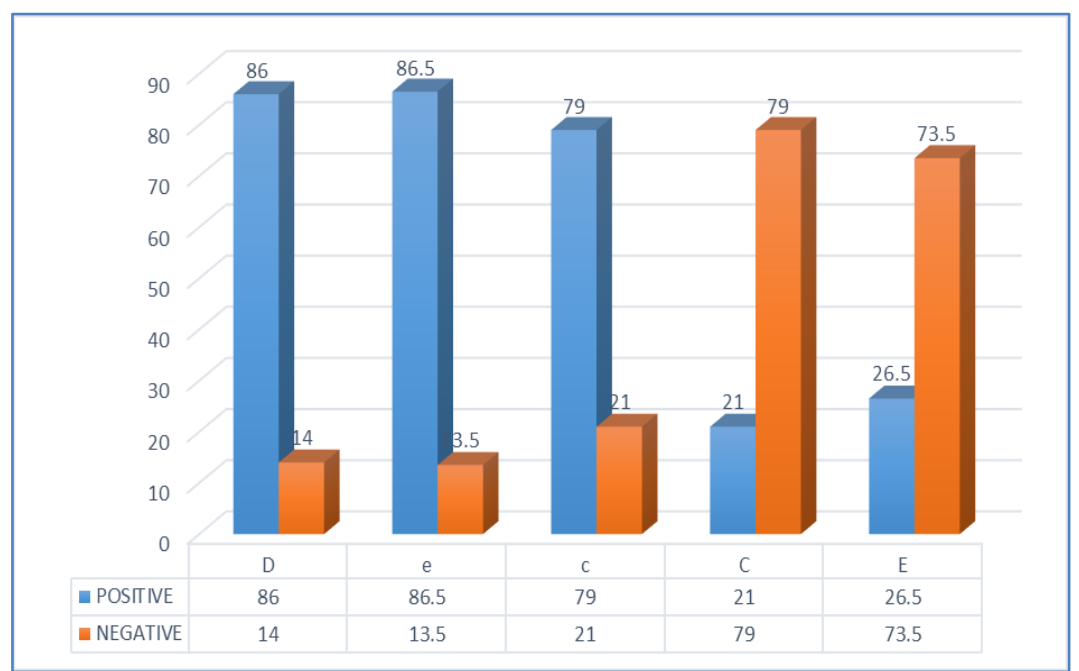

Fig-1: Distribution of frequency percentage of Rh phenotyping

\section{DISCUSSION}

The distribution of $\mathrm{ABO}$ and $\mathrm{Rh}$ blood groups is important for effective management of blood banks. It is mandatory to have information on the distribution of these blood groups in any population [11].

$\mathrm{Rh}$ antigens are highly immunogenic and till now, $49 \mathrm{Rh}$ antigens are identified. $\mathrm{D}$ antigen is most significant and $\mathrm{D}^{-}$negative individuals produce anti- D antibodies if they encounter the $\mathrm{D}$ antigen through transfusion or pregnancy and causes hemolytic transfusion reaction or hemolytic disease of fetus and newborn. For this reason, the Rh status is routinely determined in blood donors, transfusion recipients, and in pregnancy [12].

The $\mathrm{Rh}$ blood group system includes many immunogenic antigens that are located on variant forms of RhD and RhCE proteins. The genes responsible for the $\mathrm{Rh}$ proteins are located on the short arm of chromosome number one [13-15]. 
This study was performed to detect the frequencies of the various $\mathrm{Rh}$ antigens among the blood donors in National Blood Transfusion Center Khartoum.

Among participants $\mathrm{ABO}$ grouping distribution showed $\mathrm{O}(58.5 \%)$, A $(22.5 \%)$, B (15.0\%) and $\mathrm{AB}(4.0 \%)$ Table 1$)$. However the majority of ABO blood group for Sudanese people was found to be group $\mathrm{O}(58.5 \%)$ which similar to results reported in other studies $[1,16,17]$. In other research conducted in India reported the group B was highest frequency [18]. This may be because the sample in our study is small or our populationgenetic is different from India.

Our results showed the most frequent $\mathrm{Rh}$ antigen is e (86.5\%), D (86\%), c (79\%), E (26.5\%) and $\mathrm{C}(21 \%)$ respectively (figure 2$)$. The frequencies were consistent to result obtained in studies carried in Mainland Chinese and study in Uganda by and contrast to study in Malaysia [19-21].

Our research found $\mathrm{e}$ antigen is higher frequencies (86.5), while the $\mathrm{C}$ antigens were lower Frequencies $21 \%$. This was similar to finding in Asian population and whites European [22, 23]. In contrast to other studies reported the $\mathrm{E}$ antigen was major frequencies [24].

Our results indicate that the distributions of RBC antigens differ in different ethnic groups, which may be the result of different genetic and geographical origins.

The percentage of $\mathrm{D}$ antigen is $86 \%$ among the donors which contradictory to finding in other studies in Saudi Arabia [25]. Furthermore, a study that conducted on southwestern Uganda by Mbalibulha found the $96 \%$ of participants expressed D antigen [20].

The Rh D negative frequency in this study is $14.2 \%$. These results contrast with the study of the frequency to Rh-negative group in the Saudi population and Pakistan is $7 \%[26,27]$. while in Nigeria $4.8 \%$ of blood donors were found to be Rhnegative [28] and in Nepal and Guinea,3.3\% and 4.1\% were Rh-negative respectively [29, 30].The differences may be due to ethnic factors and our study demonstrate only male donors because female in our country is rarely donated blood because male is more healthier and fit than female and the female more susceptible to anemia during menstruating age in addition to pregnancy and breastfeeding inhibit them from donation.

The determination of Rhesus antigens is important to prevent hemolytic disease for new born which occur when a Rhesus negative mother pregnant with Rhesus positive fetus and prevent alloimmunization when Rhesus negative patient transfused with Rhesus positive blood.

\section{CONCLUSION}

This study conclude that the percentages of the ABO blood groups were O $(58.5 \%)$, A $(22.5 \%)$, B (15.0\%), and $\mathrm{AB}$ (4\%). Whereas the frequency percentage and $\mathrm{Rh} \mathrm{D}$ negative donors were $14 \%$. Furthermore the frequency percentages of other various $\mathrm{Rh}$ antigens were e (86.5\%), c (79\%), C (21\%), and E $(26.5 \%)$

\section{REFERENCES}

1. Elsayid M, Aseeri YY, Al Saqri F, Alanazi A, Qureshi S. A Study of Prevalence of Blood Group of Saudi Patients in King Abdulaziz Medical CityRiyadh .Science Journal of Public Health. 2015; 3(4): 559-562

2. Elsayid M, Aseeri YY, Saqri FA, Alanazi A, Qureshi S. A Study of Prevalence of Blood Group of Saudi Patients in King Abdulaziz Medical CityRiyadh. Sci J Public Health. 2015;3:559-62.

3. Reddy KS, Sudha G. ABO and Rh (D) blood groups among the desuri Reddis of Chittoor District, Andhra Pradesh. The Anthropologist. 2009 Jul 1;11(3):237-8.

4. Diedrich B, Andersson J, Sallander S, Shanwell A. $\mathrm{K}$, Fya, and Jka phenotyping of donor RBCs on microplates. Transfusion. 2001 Oct;41(10):1263-7.

5. Avent ND, Reid ME. The Rh blood group system: a review. Blood, The Journal of the American Society of Hematology. 2000 Jan 15;95(2):375-87.

6. Chou ST, Westhoff CM.The Rh and Rh AG blood group systems. Immunohematology. 2010;26(4):178-186.

7. Mbalibulha Y, Muwanguzi E, Mugyenyi G. Rhesus blood group haplotype frequencies among blood donors in southwestern Uganda. Journal of blood medicine. 2018;9:91.

8. Nance ST, Lomas- Francis C. Where are we in efforts to unravel the complexity of $\mathrm{Rh}$ to guide transfusion decisions?. Transfusion. 2013 Nov;53(11pt2):2840-3.

9. Sidhu S. Distribution of the ABO blood groups and $\mathrm{Rh}$ (D) factor among the scheduled caste population of Punjab group markers among the four scheduled caste. Anthropologist. 2003;5:2034. 11.

10. Pramanik T, Pramanik S. Distribution of ABO and Rh blood groups in Nepalese medical students: a report. East Mediterr Health J. 2000;6:156-8.

11. Enosolease ME, Bazuaye GN. Distribution of ABO and $\mathrm{Rh}^{-} \mathrm{D}$ blood groups in the Benin area of Niger-Delta: Implication for regional blood transfusion. Asian J Transfus Sci. 2008;2:3 - 5.

12. Bethesda DL. Blood groups and red cell antigens. In: The Rh Blood Group. USA: National Center for Biotechnology Information; 2005: 1 - 6. 
13. Levine $\mathrm{P}$, Stetson RE. Anunusual case of intra- $^{-}$groupagglutination. JAMA. 1939; $113: 126^{-} 7$.

14. Sharma DC, Rai S, Iyenger S, Jain B, Sao S. Prevalence and distribution $\mathrm{ABO}$ and $\mathrm{Rh}^{-} \mathrm{D}$ Antigens along with its Subgroups and rare types in greater Gwalior Region. OJBD. 2013;2:69- 73. 17.

15. Landsteiner K, Wiener AS. An agglutinable factor in human blood recognized by immune sera for rhesus blood. Proc Soc Exp Biol Med. 1940; 43:223.

16. Abu-Sin AY, Ayoub M, Abdelrazig H. Antenatal blood group serology in Sudanese women. Vox Sang. 1978; 34(6):347-50.

17. Frances TF: Blood groups (ABO groups). In: Common Laboratory and Diagnostic Tests. 3rd Edition, Philadelphia: Lippincott. 2002:19-5.

18. Purushottam A. Giri, Sankalp Yadav, Gaurav Singh Parhar, Deepak B. Phalk.Frequency of ABO and Rhesus Blood Groups: A Study from a Rural Tertiary Care Teaching Hospital in India. Int J Biol Med Res. 2011; 2(4): 988 -990.

19. Yu Y, Ma C, Sun X, Guan X, Zhang X, Saldanha J, Chen L, Wang D. Frequencies of red blood cell major blood group antigens and phenotypes in the Chinese Han population from Mainland China. International journal of immunogenetics. 2016 Aug;43(4):226-35.

20. Mbalibulha Y, Muwanguz E, Mugyenyi G. Rhesus haplotype frequencies in donor blood in Uganda. Journal of Blood Medicine. 2018:9.91-94.

21. Musa RH, Ahmed SA, Hashim H, Ayob Y, Asidin NH, Choo PY, Al-Joudi FS. Red cell phenotyping of blood from donors at the National blood center of Malaysia. Asian journal of transfusion science. 2012 Jan;6(1):3.
22. Siransy Bogui L, Dembele B, Sekongo Y, Abisse $\mathrm{S}$, Konaté S, Sombo M. Phenotypic profile of Rh and Kell blood group systems among blood donors in Cote d'Ivoire, West Africa. Journal of blood transfusion. 2014;2014.

23. Kahar MA, Patel RD. Phenotype frequencies of blood group systems (Rh, Kell, Kidd, Duffy, MNS, $\mathrm{P}$, Lewis, and Lutheran) in blood donors of south Gujarat, India. Asian journal of transfusion science. 2014 Jan;8(1):51.

24. Agarwal N, Thapliyal RM, Chatterjee K. Blood group phenotype frequencies in blood donors from a tertiary care hospital in north India. Blood research. 2013 Mar 1;48(1):51-4.

25. Elsayid M, Al Qahtani S F, Al Qarni M A, Almajed F, Al Saqri F, Qureshi S. The frequency of the most immunogenic Rhesus antigens among Saudi donors in King Abdulaziz Medical City- Riyadh. Journal of Natural Science, Biology and Medicine.2017: 8 $.56-59$

26. Rahman M and Lodhi Y. Frequency of ABO and Rhesus blood groups in blood donors in Punjab. Pak J Med Sci. 2004; 20:315-8.

27. Bashwari LA, Al Mulhim AA, Ahmad MS, Ahmed MA. Frequency of ABO blood groups in Eastern region of Saudi Arabia. Saudi Med J. 2001; 22:1008-12.

28. Mwangni J. Blood group distribution in an urban population of patient targeted blood donors. East Afr. Med .J. 1999; 76 (11): 615-8.

29. Pramanik T and S Pramanik. Distribution of ABO and $\mathrm{Rh}$ blood groups in Nepalese medical students: a report. East Mediter. Health J. 2000; 1:156-8

30. Loua A, Lamah MR, Haba NY and Camara M. Frequency of blood groups $\mathrm{ABO}$ and Rhesus D in the Guinean population. Transfus. Clin. Biol. 2007; 14 (5):435-9. 